\title{
PENGEMBANGAN APLIKASI DETEKSI DINI SERANGAN HAMA PADI BERBASIS ANDROID
}

\author{
Arief Budiman ${ }^{1}$, Pradityo Utomo ${ }^{2}$, Sri Rahayu ${ }^{3}$ \\ 1, 2 Universitas Merdeka Madiun \\ E-mail: arief@unmer-madiun.ac.id \\ ${ }^{3}$ Fakultas Pertanian Universitas Merdeka Madiun \\ E-mail: srirahayu@unmer-madiun.ac.id
}

\begin{abstract}
The era of information technology makes all aspects of life move from conventional to computerised. In Indonesia, where the majority of the population make a living as farmers have applied information technology to solve several problems. One of the issues faced by farmers is a pest attack on rice plants. As a result of pest attacks, farmers' crops become less than optimal. In this study, developed an Android-based application can be used to detect early attacks of rice pests. Development of Android-based rice pest attack applications using the Build And Fix method. The Build and Fix method choose because it is considered suitable for developing applications that are not too large. As for testing applications using the Black Box method. By using the Build And Fix method, an early detection application for Android-based rice pest attacks has been successfully created. The system built has an application capability level of $100 \%$ after being tested using the Black Box method.
\end{abstract}

Keywords : Rice, Farmer, Pest, Android-Based Application

\begin{abstract}
Abstrak. Era teknologi informasi membuat semua aspek kehidupan beralih dari konvensional ke komputerisasi. Di Indonesia yang mayoritas penduduknya bermata pencaharian sebagai petani telah menerapkan teknologi informasi dalam menyelesaikan beberapa permasalahan. Salah satu permasalahan yang dihadapi petani adalah serangan hama terhadap tanaman padi. Akibat serangan hama, hasil panen petani menjadi kurang maksimal. Pada penelitian ini dikembangkan sebuah aplikasi berbasis android yang dapat digunakan untuk mendeteksi dini serangan hama padi. Pengembangan aplikasi serangan hama padi berbasis android menggunakan metode Build And Fix. Metode Build and Fix dipilih karena dianggap cocok untuk pengembangan aplikasi yang tidak terlalu besar. Sedangkan untuk pengujian aplikasi menggunakan metode Black Box. Dengan menggunakan metode pengembangan sistem Build And Fix, telah berhasil dibuat aplikasi deteksi dini serangan hama padi berbasis android. Sistem yang dibangun memiliki tingkat kemampuan aplikasi sebesar 100\% setelah diuji menggunakan metode Black Box.
\end{abstract}

Kata Kunci: Padi, Petani, Hama, Aplikasi Berbasis Android

\section{PENDAHULUAN}

Petani adalah salah satu mata pencaharian penduduk di Indonesia yang prosentasenya cukup besar. Karena Indonesia merupakan negara agraris. Problematika yang sering dialami oleh petani padi adalah serangan hama. Beberapa wilayah di Indonesia yang tanaman padinya pernah diserang hama adalah Kecamatan Sawahan dan Wungu Kabupaten Madiun, Jawa Timur.

Berdasarkan permasalahan yang dialami oleh petani, seharusnya petani mampu melakukan identifikasi secara dini ancaman dari serangan hama. Petani harus memiliki pengetahuan akan hal tersebut. Faktanya masih terdapat petani yang tidak cukup pengetahuan tentang ancaman hama, sehingga pada akhirnya hasil panen tidak dapat maksimal, bahkan bisa terjadi kerugian yang cukup besar. Hal ini biasa dialami oleh para petani pemula, sehingga perlu pembelajaran khusus tentang ancaman serangan hama.

Seiring berkembangnya teknologi informasi, banyak bidang yang terbantu dalam menangani beberapa masalah. Pada penelitian ini, akan dibuat sebuah aplikasi deteksi dini serangan hama padi. Dipilih berbasis android, karena pada era modern ini hampir seluruh lapisan masyarakat memiliki ponsel cerdas (smartphone) yang dapat diinstall aplikasi cerdas seperti aplikasi yang dapat mengidentifikasi serangan hama.Penelitianpenelitian pengembangan aplikasi telah dibuat 
untuk mengidentifikasi hama. Beberapa diantaranya menggunakan metode Expert System Development Life Cycle (ESDLC). Salah satu penelitian dibuat oleh Rojak dan Setiawan dalam mengembangkan aplikasi sistem pakar diagnosis penyakit dan hama pada tanaman padi. Aplikasi yang dibuat berbasis web dapat mendiagnosa penyakit dan hama pada tanaman padi. Output yang diberikan bukan hanya hasil diagnosa, tetapi juga cara penanggulangannya (Rojak, 2017).

Pengembangan sistem pakar diagnosis hama menggunakan metode ESDLC juga telah dibuat berbasis android. Salah satu dianntaranya dilakukan oleh Sunarya dan Fatimah adalah pengembangan sistem pakar berbasis android yang dapat digunakan untuk diagnosa hama tanaman bawang merah. Sistem yang dibuat juga memberikan informasi terkait solusi pengobatan supaya tidak terserang wereng (Sunarya, Fatimah, 2016). Penelitian lain pengembangan sistem pakar diagnosa penyakit dan hama berbasis android diterapkan untuk tanaman semangka. Metode pengembangan sistem yang digunakan adalah ESDLC. Output dari sistem pakar ini adalah informasi mengenai hasil diagnosa penyakit hama dan solusi pengobatan (Munawaroh, Fatimah, 2016).

Pada penelitian ini akan dibuat aplikasi deteksi dini serangan hama tanaman padi berbasis android dengan menggunakan metode Built And Fix. Beberapa penelitian pemanfaatan metode Built And Fix untuk pengembangan aplikasi berbasis android dan metode Black Box untuk pengujian juga telah dilakukan. Salah satunya dilakukan oleh
Prasetya,dkk membuat aplikasi penunjuk arah kiblat dan pengingat waktu sholat berbasis android pada era regional Kota Madiun. Setelah dilakukan pengujian menggunakan metode Black Box, aplikasi tersebut memiliki keberhasilan sebesar $100 \%$ (Prasetya,dkk, 2017). Penelitian lain yang menggunakan metode Build And Fix dan Black Box juga dilakukan oleh Yoyok,dkk. Pada penelitian tersebut dibuat aplikasi delivery makanan Padang berbasis android pada Rumah Makan Ampera Salero. Customer dapat dengan mudah memesan makanan pada Rumah Makan Ampera Salero. Aplikasi tersebut memiliki tingkat keberhasilan $100 \%$ diuji menggunakan metode BlackBox (Yoyok,dkk, 2017). Dengan mengacu beberapa penelitian tersebut, pada penelitian ini akan dibuat aplikasi deteksi dini serangan hama tanaman padi berbasis android menggunakan metode Build And Fix.

\section{METODE PENELITIAN}

Metode penelitian yang digunakan mengadopsi metode pengembangan aplikasi. Aplikasi deteksi dini serangan hama padi berbasis android menggunakan model Build And Fix. Karena pengembangan aplikasi deteksi dini serangan hama padi berbasis android membutuhkan waktu yang cepat. Dengan menggunakan metode Build And Fix mampu melakukan pengembangan aplikasi yang meliputi pembuatan dan perbaikan tanpa membutuhkan waktu yang lama berbulan-bulan (Syafaat, 2011). Adapun tahapan dari metode Build And Fix dapat dapat dilihat pada Gambar 1.

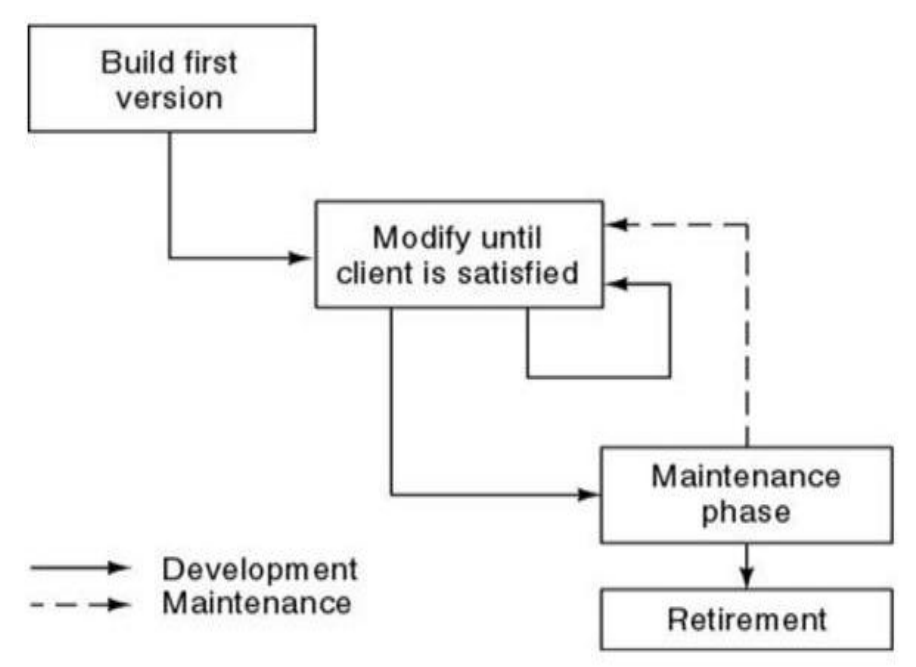

Gambar 1. Build And Fix Method (Lochi,2005) 
Pada Gambar 1 telah ditampilkan dari metode Build And Fix dalam pengembangan aplikasi. Tahapan yang pertama adalah Build First Version, dimana aplikasi dibuat versi pertama berdasarkan kebutuhan-kebutuhan dan penjelasan dari customer yang dalam hal ini melibatkan user. User adalah pihak yang akan menggunakan aplikasi. Setelah aplikasi selesai dibuat bersi pertama, selanjutnya tahapan Modify Until Client Customer Satisfied. Pada tahapan ini, user melakukan evaluasi terhadap aplikasi awal yang telah dibuat. User juga memberikan komentar jika terjadi perbedaan pendapat terhadap aplikasi yang diinginkan user. Jika terjadi ketidak puasan user, maka programer akan memperbaiki aplikasi sampai menjadi aplikasi fix sesuai dengan harapan dan kebutuhan user.

Tahapan ketiga adalah Maintenance. Tahap Maintenance akan dilakukan jika aplikasi yang sudah selesai, ternyata terdapat eror atau kerusakan saat implementasi. Dengan menggunakan metode Build And Fix, maka programer berkewajiban melakukan perbaikan sampai user terpuaskan dengan aplikasi yang telah dibuat. Tahapan yang terakhir adalah Retirement. Retirement merupakan tahapan saat user sudah tidak menggunakan aplikasi yang dibuat programmer. Sehingga model Build And Fix ini cocok untuk pembuatan aplikasi yang pengerjaannya dalam waktu yang cukup singkat.
Selain metode pengembangan aplikasi, penelitian ini menggunakan metode Black Box untuk pengujian aplikasi.Pengujian Black Box lebih mengarah pada fungsionalitas aplikasi. Beberapa keuntungan menggunakan pengujian Black Box antara lain (Mustaqbal, 2015) :

1. Ketepatan fungsional aplikasi

2. Ketepatan antarmuka aplikasi

3. Ketepatan struktur data aplikasi

4. Ketepatan basis data

\section{HASIL DAN PEMBAHASAN}

Pada bagian Hasil dan analisis, akan dibahas mulai analisis, desain, implementasi pembuatan aplikasi, dan pengujian aplikasi.

\section{Analisis dan Desain}

Aplikasi deteksi dini serangan hama padi diharapkan dapat membantu petani dalam mencegah serangan hama padi. Petani dapat melakukan analisa terhadap padi di sawah menggunakan aplikasi yang diinstal pada smartphone berbasis android. Aplikasi berbasis android memiliki web server yang bertugas sebagai admin, sehingga petani yang bertindak sebagai user dapat dengan mudah menggunakan aplikasi deteksi dini serangan hama padi. Desain Aplikasi dapat dilihat pada Gambar 2.

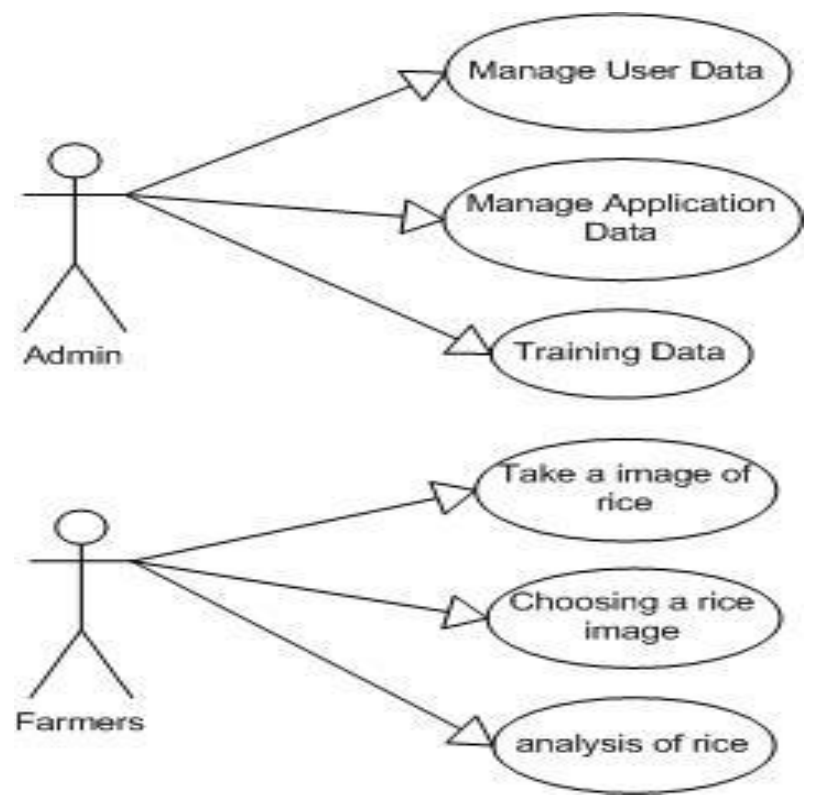

Gambar 2. Use Case Diagram 
Pada Figure 2 telah disajikan Use Case Diagram dari aplikasi deteksi dini serangan hama padi berbasis android. Dimana aplikasi memiliki dua aktor yaitu admin dan petani. Admin bertindak sebagai pengelola web server, yang dapat mengelola data user, mengelola data aplikasi, dan training data. Dalam mengelola data aplikasi, admin dapat menambah, mengedit, dan menghapus data. Untuk petani yang bertindak sebagai pengguna aplikasi android dapat melakukan

pengambilan image, pemilihan image, dan analisis padi.

\section{Implementasi}

Pada implementasi pembuatan aplikasi, dibuat berdasarkan desain aplikasi. Pembahasan implementasi aplikasi akan disajikan berdasarkan dua aktor, admin dan petani. Admin dalam mengelola data training dapat dilihat pada Gambar 3.

\begin{tabular}{|c|c|c|c|c|c|c|c|c|c|}
\hline \multicolumn{2}{|c|}{ POST $>$} & \multicolumn{4}{|c|}{ http://localhost:8080/input-data-training } & Params & Send $\quad \checkmark$ & Save & $\checkmark$ \\
\hline \multicolumn{2}{|c|}{ Authorization } & Headers & Body $\bullet$ & Pre-request Script & Tests & & & \multicolumn{2}{|c|}{ Cookies Code } \\
\hline \multicolumn{2}{|c|}{ form-data } & $x-w w w-f o$ & rm-urlencoded & raw & binary & & & & \\
\hline & Key & & & & Value & Description & & \multicolumn{2}{|c|}{ Bulk Edit } \\
\hline$\checkmark$ it & img_folder & & & & /home/linuxluv/Documents/uns/research/didit_img/i... & & & & \\
\hline \multirow[t]{2}{*}{$\checkmark$} & kelas & & & & 2 & & & & \\
\hline & New key & & & & Value & Description & & & \\
\hline Body & Cookies & Header & $s(3)$ & st Results & & Status: $200 \mathrm{OK}$ & Time: $1812 \mathrm{~ms}$ & Size: 14 & 43 B \\
\hline Pretty & Raw & Preview & Text $>$ & $\bar{\varsubsetneqq}$ & & & $\square \mathrm{Q}$ & Save Respor & onse \\
\hline
\end{tabular}

\section{Gambar 3. Manage Data Aplikasi}

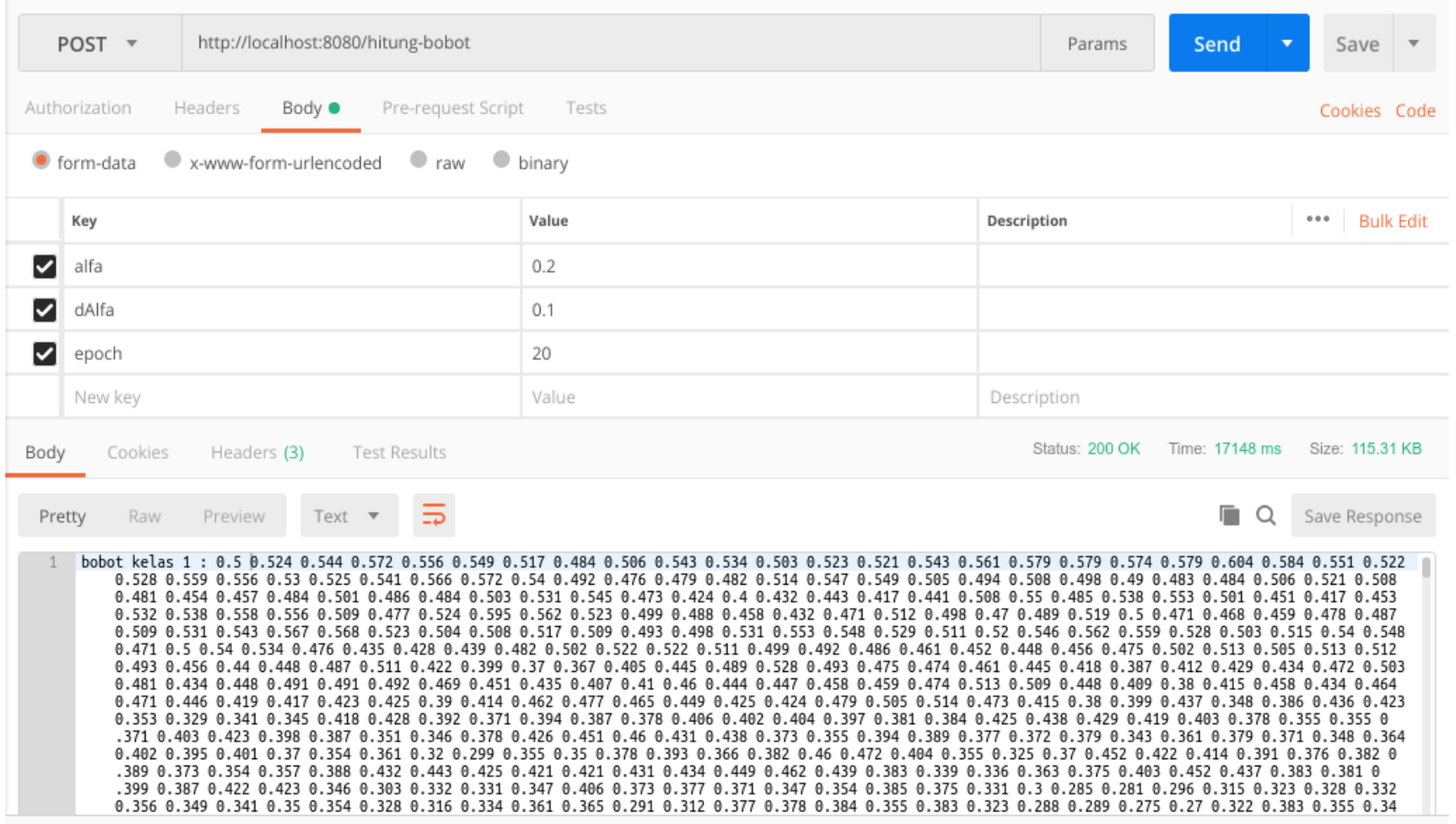

Gambar 4.Training Data 
Menurut Gambar 3, admin dapat mengelola data aplikasi. Admin dapat menambah, mengedit, dan menghapus data. Data aplikasi yang dimasukkan berupa image, yang kemudian dipilih kelas menurut jenis data. Jenis data yang digunakan adalah Image padi yang sehat dan image padi yang terserang hama. Jika terdapat kesalahan dalam pemilihan kelas, admin dapat mengedit data, kemudian disimpan ulang. Admin juga dapat menghapus data jika terjadi kesalahan pada data. Setelah data dimasukkan, admin melakukan pelatihan data untuk mendapatkan bobot akhir. Dimana bobot akhir digunakan sebagai acuan untuk pengenalan data

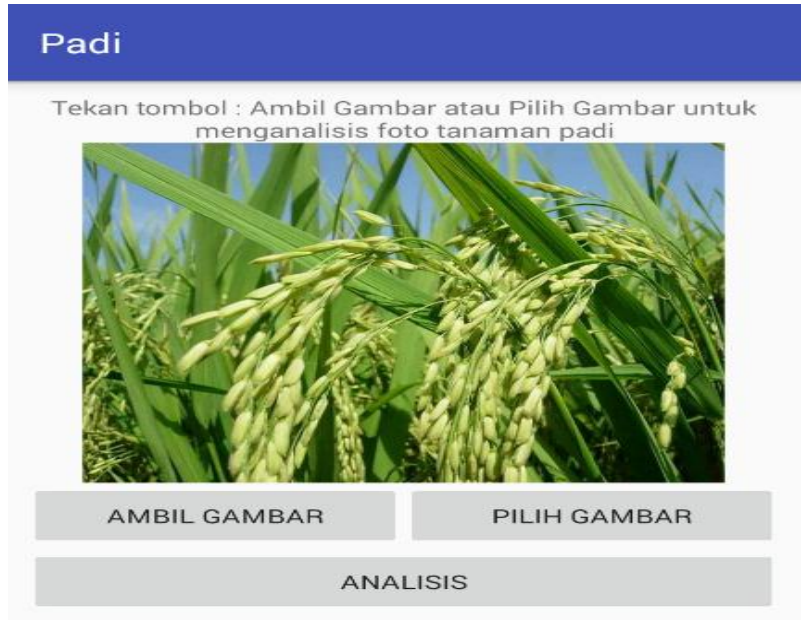

\section{Gambar 5. Aplikasi Deteksi Dini Serangan Hama Padi Berbasis Android}

Gambar 5 merupakan tampilan dari aplikasi deteksi dini serangan hama padi berbasis android. Pada aplikasi berbasis android terdapat tiga tombol, yaitu ambil gambar, pilih gambar, dan analisis. Ambil gambar digunakan untuk memotret secara langsung data yang akan dianalisis. Untuk tombol pilih gambar digunakan untuk memilih gambar yang sudah tersedia dalam galeri smartphone. Setelah imager terpilih, kemudian user dapat melakukan analisis dari data. Tampilan dari analisis data dapat dilihat pada Gambar 6. Pada hasil analisis data seperti yang ditunjukkan Gambar 6, data akan dikenali sebagai data padi sehat atau padi yang terserang hama. baru.

Training data yang disajikan pada Gambar 4 dapat dilakukan setelah pengisian nilai alfa, penurunan alfa, dan epoch. Kemudian admin dapat melakukan pelatihan data untuk sistem mendapat pengetahuan. Setelah admin melatih data, aplikasi berbasis android dapat digunakan petani dalam mengenali data baru. Data baru yang dimaksud adalah image tanaman padi yang sehat atau yang terserang hama padi, sehingga aplikasi berbasis android dapat digunakan untuk mengenali image baru. Adapun tampilan dari aplikasi berbasis android dapat dilihat pada Gambar

\section{Padi}

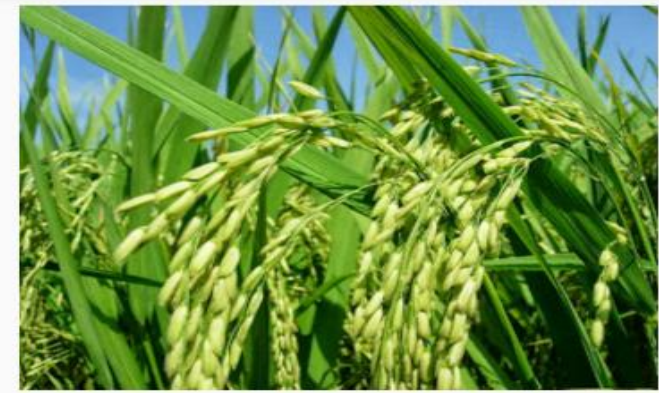

Hasil analisis :

Padi sehat, tidak terserang hama wereng

Gambar 6. Analisis data baru

\section{Pengujian}

Pengujian Black Box dilakukan dengan mengujikan beberapa aspek fungsional aplikasi. Metode ini dapat memberikan kesimpulan ketepatan dan kemudahan user dalam menggunakan aplikasi deteksi dini serangan hama padi berbasis android. Skenario pengujian aplikasi dibagi menjadi dua bagian, yaitu pengujian web server dan aplikasi android. Adapun pengujian Web Server dapat dilihat pada Tabel 1. 
Tabel 1. Pengujian Web Server

\begin{tabular}{|c|c|c|c|c|c|}
\hline No & $\begin{array}{c}\text { Skenario } \\
\text { Pengujian }\end{array}$ & Tes & $\begin{array}{l}\text { Hasil Yang } \\
\text { Diharapkan }\end{array}$ & Hasil & Kesimpulan \\
\hline 1 & $\begin{array}{l}\text { Mengosongkan } \\
\text { isian data login, } \\
\text { kemudian klik } \\
\text { tombol Sign In }\end{array}$ & $\begin{array}{l}\text { Username: } \\
- \\
\text { Password : } \\
-\end{array}$ & $\begin{array}{l}\text { Aplikasi } \\
\text { menolak akses } \\
\text { login }\end{array}$ & $\begin{array}{l}\text { Sesuai } \\
\text { Harapan }\end{array}$ & Valid \\
\hline 2 & $\begin{array}{l}\text { Menginputkan } \\
\text { data login yang } \\
\text { benar, kemudian } \\
\text { klik tombol Sign } \\
\text { In }\end{array}$ & $\begin{array}{l}\text { Username: } \\
\text { admin } \\
\text { Password : } \\
\text { admin }\end{array}$ & $\begin{array}{l}\text { Aplikasi } \\
\text { menerima } \\
\text { login, } \\
\text { kemudian } \\
\text { menampilkan } \\
\text { Home }\end{array}$ & $\begin{array}{l}\text { Sesuai } \\
\text { Harapan }\end{array}$ & Valid \\
\hline 3 & $\begin{array}{l}\text { Tambah data } \\
\text { admin, edit data, } \\
\text { dan hapus data }\end{array}$ & $\begin{array}{l}\text { Klik button } \\
\text { tambah, } \\
\text { edit, dan } \\
\text { hapus }\end{array}$ & $\begin{array}{l}\text { Aplikasi } \\
\text { menerima } \\
\text { inputan dan } \\
\text { perubahan } \\
\text { data }\end{array}$ & $\begin{array}{l}\text { Sesuai } \\
\text { Harapan }\end{array}$ & Valid \\
\hline 4 & $\begin{array}{l}\text { Melakukan } \\
\text { pelatihan data }\end{array}$ & $\begin{array}{l}\text { Klik } \\
\text { Tombol } \\
\text { Training }\end{array}$ & $\begin{array}{l}\text { Aplikasi } \\
\text { mendapatkan } \\
\text { bobot baru } \\
\text { setelah } \\
\text { pelatihan data }\end{array}$ & $\begin{array}{l}\text { Sesuai } \\
\text { Harapan }\end{array}$ & Valid \\
\hline 5 & Keluar Aplikasi & $\begin{array}{l}\text { Klik } \\
\text { tombol } \\
\text { keluar }\end{array}$ & $\begin{array}{l}\text { Aplikasi } \\
\text { menerima } \\
\text { perintah untuk } \\
\text { keluar aplikasi }\end{array}$ & $\begin{array}{l}\text { Sesuai } \\
\text { Harapan }\end{array}$ & Valid \\
\hline
\end{tabular}

Tabel 2. Pengujian Aplikasi Android

\begin{tabular}{|c|l|l|l|l|l|}
\hline No & $\begin{array}{l}\text { Skenario } \\
\text { Pengujian }\end{array}$ & \multicolumn{1}{|c|}{ Tes } & Hasil Yang Diharapkan & Hasil & Kesimpulan \\
\hline 1 & $\begin{array}{l}\text { Memotret } \\
\text { data baru }\end{array}$ & $\begin{array}{l}\text { Klik ambil } \\
\text { gambar }\end{array}$ & $\begin{array}{l}\text { Aplikasimemotret } \\
\text { gambar }\end{array}$ & $\begin{array}{l}\text { Sesuai } \\
\text { Harapan }\end{array}$ & Valid \\
\hline 2 & $\begin{array}{l}\text { Memilih } \\
\text { data baru } \\
\text { (gambar) }\end{array}$ & $\begin{array}{l}\text { Klik pilih } \\
\text { gambar }\end{array}$ & $\begin{array}{l}\text { Aplikasidapat } \\
\text { memilih gambar dari } \\
\text { galeri }\end{array}$ & $\begin{array}{l}\text { Sesuai } \\
\text { Harapan }\end{array}$ & Valid \\
\hline 3 & $\begin{array}{l}\text { Melakukan } \\
\text { analisa } \\
\text { gambar }\end{array}$ & Klik analisa & $\begin{array}{l}\text { Aplikasimemberikan } \\
\text { hasil analisa }\end{array}$ & $\begin{array}{l}\text { Sesuai } \\
\text { Harapan }\end{array}$ & Valid \\
\hline
\end{tabular}

Selain pengujian terhadap Web Server, pengujian juga dilakukan terhadap aplikasi android yang digunakan user. Adapun pengujian terhadap aplikasi android dapat dilihat pada Tabel 2 . Berdasarkan tabel 1 dan 2, telah disajikan skenario pengujian dari aplikasi. Dari lima skenario pengujian web server, terdapat lima kesimpulan yang valid. Sedangkan untuk tiga skenario pengujian aplikasi android, terdapat tiga kesimpulan yang valid. Sehingga dapat disimpulkan aplikasi deteksi dini serangan hama padi berbasis android memiliki akurasi keberhasilan $100 \%$ berdasarkan hasil pengujian black box. 


\section{SIMPULAN DAN SARAN}

Pada penelitian ini, dapat disimpulkan bahwa telah berhasil dikembangkan aplikasi deteksi dini serangan hama padi berbasis android. Aplikasimemiliki tingkat akurasi keberhasilan sebesar $100 \%$ berdasarkan hasil pengujian black box.Pada penelitian berikutnya dapat dikembangkan menggunakan metode jaringan saraf tiruan yang lain, dan menggunakan jumlah data yang lebih banyak.

\section{DAFTAR PUSTAKA}

Lochi F, 2005, Software Engineering II.

Munawaroh I S., Fatimah D D S., 2016, Pengembangan Sistem Pakar Diagnosis Penyakit dan Hama Pada Tanaman Bawang Merah Berbasis Android, Jurnal Algoritma Sekolah Tinggi Teknologi Garut, ISSN : 2302-7339 Vol. 13 No. 1.

Mustaqbal S M., Firdaus R F., Rahmadi H., 2015, Pengujian Aplikasi Menggunakan Black Box Testing Boundary Value Analysis(Studi Kasus : Aplikasi Prediksi Kelulusan SNMPTN). Jurnal Ilmiah Teknologi Informasi Terapan. ISSN:2407-3911.

Prasetya O D., Budiman A., Triono J., 2017, Aplikasi Penunjuk Arah Kiblat dan Pengingat Waktu Sholat Berbasis Android Pada Era Regional Kota Madiun. Prosiding Seminar Nasional Hasil-Hasil Penelitian dan Pengabdian Tahun 2017. Madiun. ISBN:978602-397-159-6. Page: 199-205.

Rojak., Setiawan R., 2017, Pengembangan Aplikasi Sistem Pakar Diagnosis Penyakit dan Hama Pada Tanaman Padi. Jurnal Algoritma Sekolah Tinggi Teknologi Garut. ISSN : 2302-7339 Vol. 14 No. 02.

Sunarya R., Fatimah D D S., 2016, Pengembangan Sistem Pakar Diagnosis Hama dan Penyakit Pada Tanaman Bawang Merah Berbasis Android. Jurnal Algoritma Sekolah Tinggi Teknologi Garut. ISSN : 2302-7339 Vol. 13 No. 1.

Syafaat, 2011, Android : Pemrograman Aplikasi Mobile Smartphone dan Tablet PC. Yogyakarta.

Yoyok R., Budiman A., Triono J., 2017, Aplikasi Delivery Makanan Padang Berbasis Android Pada Rumah MAkan Ampera Salero. Prosiding Seminar Nasional Hasil-Hasil Penelitian dan Pengabdian Tahun 2017.
Madiun. 2017. ISBN:978-602-397-159-6.

Page: 213-222. 